\title{
MISKONSEPSI MAHASISWA PADA MATERI HIMPUNAN: ANALISIS MENGGUNAKAN KRITERIA CERTAINTY OF RESPONSE INDEX
}

\author{
Hermina Disnawati ${ }^{*}$, Yohanis Ndapa Deda ${ }^{2}$ \\ ${ }^{1,2}$ Prodi Pendidikan Matematika Fakultas Ilmu Pendidikan, Universitas Timor \\ Jalan Eltari Km.09 Kelurahan Sasi, Kefamenanu, Indoneisa \\ e-mail: 1disnawati@unimor.ac.id;
}

Submitted: November 26,2021

Revised: January 8, 2022

Accepted: January 22, 2022

corresponding author*

\begin{abstract}
Abstrak
Penelitian ini bertujuan untuk mengetahui miskonsepsi mahasiswa tentang konsep himpunan menggunakan indikator certainty of response index (CRI). Subjek penelitian terdiri dari 89 orang mahasiswa semester 1 yang memprogram mata kuliah Pengantar Dasar Matematika (PDM). Metode penelitian yamg digunakan merupakan deskriptif kualitatif. Tes tertulis terdiri dari 4 soal pilihan ganda beralasan dan uraian digunakan untuk mengumpulkan data penelitian. Hasil penelitian menunjukkan bahwa berdasarkan kriteria CRI, untuk soal nomor 1 tentang perbedaan himpunan dan bukan himpunan, terdapat 39\% mahasiswa mengalami miskonsepsi, 33\% mahasiswa tidak tahu konsep dan 28\% mahasiswa yang mengetahui konsep dengan benar. Pada soal nomor 2 tentang tiga cara menyajikan himpunan bilangan asli, cacah, prima dan bulat, ditemukan terdapat $12 \%$ mahasiswa mengalami miskonsepsi dan sebanyak $76 \%$ mahasiswa tidak tahu konsep karena menebak dan kurangnya pengetahuan, sisanya $11 \%$ mahasiswa memahami konsep dengan baik. Untuk soal nomor 3, tentang operasi himpunan ditemukan terdapat 30\% mahasiswa mengalami miskonsepsi, $45 \%$ tidak tahu konsep dan sisanya $24 \%$ memamahi konsep dengan tepat. Selanjutnya untuk soal nomor 4, soal cerita operasi himpunan diperoleh hasil bahwa dari $19 \%$ mahasiswa yang mengikuti tes mengalami miskonsepsi, $57 \%$ mahasiswa tidak paham konsep dan hanya $24 \%$ mahasiswa yang memahami konsep dengan benar. Dengan kata lain, dari 4 soal yang diujikan kepada mahasiswa, soal nomor 1 dan 3 paling banyak ditemukan mahasiswa mengalami miskonsepsi. Meskipun soal nomor 2, ditemukan paling sedikit mahasiswa mengalami miskonspesi namun pada soal ini hampir $80 \%$ mahasiswa tidak tahu konsep dengan benar.
\end{abstract}

Kata Kunci: certainty of response index, miskonsepsi, konsep himpunan

\section{STUDENT'S MISCONCEPTION ON CONCEPT OF SET: AN ANALYSIS USING CERTAINTY OF RESPONSE INDEX CRITERIA}

\begin{abstract}
This research aims to find out the misconceptions of students about the concept of the set using certainty of response index (CRI) indicators. The research subjects consisted of 89 students who programmed the Introduction to Basic Mathematics (PDM) course. The research method used is qualitative descriptive. A written test consisting of 4 reasoned multiple choice and descriptive questions were used to collect research data. The results showed that based on CRI criteria, for problem number 1 about the differences of set and not sets, there were $39 \%$ of students experiencing misconceptions, $33 \%$ of students do not know the concept and $28 \%$ of students who know the concept correctly. In question number 2 , the questions about three ways of presenting a set of natural, whole, prime and integers numbers, it was found that $12 \%$ of students experienced misconceptions and $76 \%$ of students did not know the concept because of guessing and lack of knowledge, the remaining $11 \%$ of students understand the concept very well. For problem number 3 , about the operation of the set found that $30 \%$ of students experienced misconceptions, $45 \%$ did not know the concept and the remaining $24 \%$ understood the concept correctly. Furthermore, for problem number 4 , the set operation story was obtained the result that of $19 \%$ of students who took the test experienced misconceptions, $57 \%$ of students did not understand the concept and only $24 \%$ of students understood the concept correctly. In other words, of the 4 questions that were tested on students, questions number 1 and
\end{abstract}


3 were mostly found by students experiencing misconceptions. Although problem number 2 , it was found that at least students experienced misconspection but in this questions almost $80 \%$ of students did not know the concept correctly.

Keywords: certainty of response index, misconception, set concept

\section{Pendahuluan}

Pengantar Dasar Matematika (PDM) merupakan salah satu mata kuliah wajib yang harus diprogram pada semester pertama oleh mahasiswa Program Studi Pendidikan Matematika (PSPM) Universitas Timor. Mata kuliah PDM berisi pengulangan intisari dari konsep matematika dasar yang telah dipelajari mahasiswa ketika masih di SMP dan SMA. Dalam sturuktur kurikulum PSPM, PDM menjadi MK prasyarat untuk mata kuliah lain seperti Matematika Diskrit, Kalkulus, Analisis Vektor dan Struktur Aljabar. Himpunan merupakan salah satu materi pertama yang dipelajari dalam PDM. Materi ini harus difokuskan pada penguasaan konsep, pemilihan metode belajar yang tepat, penentuan strategi, dan keterampilan belajar yang tepat sebagai persiapan untuk kelas berikutnya. Hal ini dikarenakan konsep himpunan merupakan prasyarat untuk mempelajari konsep selanjutnya penting untuk dikuasai dan dipahami (Rahmawati, N. K., Kusuma, 2019).

Berdasarkan hasil tes terhadap 89 orang mahasiswa PSPM terdapat 64 orang yang masih melakukan kesalahan saat menyelesaikan soal tentang perbedaan himpunan dan bukan himpunan. Artinya hanya 25 orang saja yang memahami konsep himpunan dengan benar. Padahal, materi tersebut merupakan konsep dasar dan prasyarat yang harus dipahami sebelum melanjutkan ke materi yang lain. Dari berbagai kesalahan yang dilakukan mahasiswa peneliti menduga salah satu penyebabnya karena terjadinya miskonsepsi. Hal ini didukung oleh kenyataan bahwa tidak semua mahasiswa baru yang kuliah di PSPM berasal dari siswa program IPA. Ada banyak mahasiswa dari jurusan lain seperti IPS, Bahasa, Administrasi Perkantoran, SMK Jurusan Tata Busana dan Teknik Komputer Jaringan. Dengan latar belakang jurusan sekolah menengah yang berbeda, PSPM juga belum menerapkan adanya matrikulasi bagi mahasiswa baru. Kondisi ini sangat menyulitkan baik mahasiswa maupun dosen karena belum ada standar awal sebelum memasuki kuliah.

Beberapa sebab rendahnya hasil belajar PDM adalah sebagai berikut: (1) Mahasiswa kurang menguasai materi prasyarat tentang konsep bilangan; (2) Mahasiswa kurang cermat dan teliti dalam memahami maksud soal sehingga tidak menjawab pertanyaan; (3).Kurang mempersipakan diri misalkan tidak mempelajari materi kuliah secara mandiri sebelum perkuliahan dimulai. Banyaknya kesalahan yang dilakukan siswa dalam pemecahan masalah dapat menunjukkan seberapa baik mereka telah menguasai materi yang ada. Dari kesalahan yang dilakukan, sumber kesalahan siswa dan upaya penyelesaiannya dapat diteliti dan dipelajari lebih lanjut. Berdasarkan uraian tersebut, maka perlu menggali informasi tentang faktorfaktor penyebab kesulitan siswa dan mengetahui dimana kesalahan siswa dalam menyelesaikan soal PDM.

Mengidentifikasi miskonsepsi pada peserta didik sangat penting dilakukan dengan tujuan untuk mencegah terjadinya rantai kesalahan konsep yang dapat muncul pada jenjang pendidikan selanjutnya (Fitria, 2014a). Pemahaman konsep yang keliru jika tidak segera diatasi maka akan berdampak pada terhambatnya proses belajar siswa dan miskonsepsi tersebut akan terus dibawa ke jenjang pendidikan yang lebih tinggi (Putri, R.E., Hasan, 2021). Hal ini dapat mengakibatkan rendahnya prestasi siswa dalam belajar.

Ada banyak penelitian yang telah dilakukan untuk menganalisis miskonsepsi seeprti melalui tes diagnostik dalam bentuk two - tier multiple choice yang dikembangkan oleh (Treagust, 2012). Teknik two-tier multiple choice memuat dua tingkatan soal dimana tingkatan pertama merupakan isi soal yang memiliki dua alternatif jawaban dan tingkatan kedua harus mengemukakan alasan mengapa memilih jawaban tersebut pada pillihan pertama (Qurrota \& Nuswowati, 2018). Namun metode tersebut masih memiliki kelemahan karena belum mampu membedakan apakah peserta didik melakukan kesalahan karena mengalami miskonsepsi atau karena tidak paham konsep (Fadillah, 2017).

Untuk mengatasi kekurangan tersebut maka dalam penelelitian ini menggunakan metode Certainty Response Index (CRI) karena CRI mampu membedakan kemampuan siswa ke dalam empat kategori yaitu memahami konsep, tidak paham konsep karena menebak, tidak paham konsep karena kurangnya pemahaman dan mengalami miskonsepsi. CRI biasanya digunakan dalam penelitian sosial sains khususnya dalam survei dimana responden diminta untuk 
menentukan penilaiannya sendiri tingkat kepastian atas jawaban yang diberikan CRI (Hasan et al., 1999). Metode ini umunya cocok diaplikasikan dalam bidang sains, matematika teknik dan bidang lain dari sekolah menengah hingga perguruan tinggi (Hasan et al., 1999). CRI memiliki 6 skala yang dimulai dari 0 sampai dengan 5. Skala 0 menunjukkan bahwa responden tidak tahu konsep sama sekali dan biasanya unsur menebak lebih banyak berperan. Sebaliknya skala 5 menunjukkan keyakinan yang sangat tinggi pada diri responden dan unsur menbak sangat kecil. Dengan kata lain, semakin rendah skala yang dipilih responden maka makin kecil keyakinannya, makin tinggi maka keyakinannya makin pasti. CRI dapat membedakan peserta didik yang mengalami miskonsepsi dengan peserta didik yang tahu konsep dengan mengukur tingkat keyakinan ketika menjawab tiap item soal yang diberikan (Fadillah, 2017; Udil, Afrisno, Amsikan \& Oktovianus, 2020).

\section{Metode Penelitian}

Metode yang digunakan dalam penelitian adalah deskriptif kualitatif. Adapun prosedur penelitian yang dilakukan yaitu (i) penentuan kelas dan subjek penelitian; (ii) pembuatan instrumen penelitian. Instrumen tes berupa 4 soal pilihan ganda beralasan dan soal uraian terkait materi himpunan. Setiap soal diberikan indeks CRI untuk mengisi tingkat keyakinan mahasiswa pada setiap jawaban yang diberikan; (iii) uji validasi soal oleh dua orang validator dan uji keterbacaan oleh seorang mahasiswa yang bukan merupakan kelas penelitian; (iv) pengumpulan data penelitian melalui pemberian tes kepada 89 orang mahasiswa di tiga kelas yang berbeda yaitu kelas A, B dan C. Pada setiap soal mahasiswa diminta menjawab soal dengan tepat dan menuliskan indeks keyakinan terhadap jawabannya yaitu angka 0-5 dengan 5 menunjukkan paling yakin. (v) Analisis data. Pada tahap ini semua pekerjaan mahasiswa diperiksa dengan cara melihat pilihan jawaban dari setiap nomor soal dan indeks CRI yang dipilih. Analisis terjadinya miskonsepsi dapat dibedakan dengan cara membandingkan benar tidaknya jawaban peserta didik dengan tinggi rendahnya indeks CRI (Ramadhan et al., 2020; Sadhu et al., 2017; Suwarna, 2017). Jika jawaban yang diberikan salah namun mahasiswa memilih indeks CRI yang tinggi maka dapat dikategorikan sebagai miskonsepsi.

Indikator indeks CRI yang membedakan siswa yang memahami konsep, tidak tahu konsep dan miskonsepsi ditunjukkan pada Tabel 1.
Tabel 1. Kriteria Jawaban Mahasiswa

\begin{tabular}{ccc}
\hline $\begin{array}{c}\text { Kriteria } \\
\text { Jawaban }\end{array}$ & CRI Rendah $(<2,5)$ & $\begin{array}{c}\text { CRI Tinggi } \\
(>2,5)\end{array}$ \\
\hline Jawaban benar & $\begin{array}{c}\text { Tidak tahu konsep } \\
\text { (lucky guess) }\end{array}$ & $\begin{array}{c}\text { Menguasai } \\
\text { konsep } \\
\text { dengan baik }\end{array}$ \\
\hline $\begin{array}{c}\text { Jawaban } \\
\text { salah }\end{array}$ & $\begin{array}{c}\text { Tidak tahu konsep } \\
\text { (a lack of } \\
\text { knowledge })\end{array}$ & Miskonsepsi \\
\hline
\end{tabular}

(Hasan et al., 1999; A’yun et al., 2018)

Tabel 2. Skala CRI dan Kriterianya

\begin{tabular}{cc}
\hline Skala CRI & Kriteria \\
\hline 0 & Totally guessed answer / pasti menebak \\
1 & Almost guess / hampir menebak \\
2 & Not sure/ tidak yakin \\
3 & Sure/yakin \\
4 & Almost Certain /hampir yakin \\
5 & Certain/sangat yakin \\
\hline
\end{tabular}

(Hasan et al., 1999; Putra et al., 2018)

Berdasarkan tabel 2 diatas jika responden memilih tingkat keyakinan 0 artinya jawaban yang diberikan hanya menebak saja. Dengan kata lain menjawab soal dengan $100 \%$ murni hasil tebakan. Jika memilih 1 maka terdapat unsur menebak sebesar $75-99 \%$. Jika memilih 2 berarti faktor menebak berada diantara 50-74\%. Selanjutnya jika responden memilih 3 , unsur tebakan berada diantara 25-49\% dan memilih indeks CRI 4 artinya masih terdapat faktor menebak pada kisaran 024\%. Sementara itu, jika responden memilih CRI skala 5 , hal itu berarti responden menjawab dengan sangat yakin tanpa ada keraguan artinya tidak ada unsur tebakan sama sekali (Putra et al., 2018)

Untuk mengetahui proporsi antara peserta kuliah yang paham konsep, tidak paham konsep dan mengalami miskonsepsi maka dilakukan perhitungan dengan menggunakan rumus berikut ini:

$$
P=\frac{F}{N} x 100 \% \quad \text { (Kefi et al., 2021) }
$$

Keterangan:

$\mathrm{P}$ : Persentase

F : Jumlah responden setiap kelompok

$\mathrm{N}$ : Banyaknya individu dalam subjek penelitian

Sumber data dan informasi dilakukan dengan triangulasi, yaitu wawancara, tes tertulis dan dokumen catatan lapangan.

\section{Hasil dan Pembahasan}

Penelitian ini menggunakan empat nomor soal materi himpunan dimana setiap soal yang diberikan kepada mahasiswa dilengkapi dengan tingkat CRI. Dipilihnya materi himpunan dengan alasan karen materi ini merupakan materi pertama 
yang diterima mahasiswa semester satu sesuai dengan kurikulum PSPM. Mahasiswa diminta untuk menjawab soal dan menentukan sendiri tingkat CRI yang berkisar $0-5$. Pada soal nomor 1 mahasiswa diminta untuk menentukan mana yang termasuk himpunan dan mana yang bukan himpunan disertai alasan yang jelas. Nomor 2 bagaimana menentukan cara menyajikan himpunan dengan tiga cara yang berbeda : dengan mendaftarkan anggota-anggotanya, menyatakan sifat keanggotaan dan menyatakan dengan notasi pembentuk himpunan. Pada soal nomor 3 dan 4 mahasiswa diminta untuk mengerjakan butir soal yang berkaitan dengan konsep operasi himpunan dalam kehidupan sehari-hari.

Setelah memerikasa, memberikan skor dan menilai hasil tes yang dikerjakan oleh mahasiswa, langkah selanjutnya adalah mengelompokkan jawaban mahasiwa ke dalam 4 indikator CRI seperti pada tabel 3 dengan kategori mahasiswa tidak tahu konsep karena menebak dan minimnya pengetahuan dasar, memiliki pemahaman konsep yang baik, dan yang mengalami miskonsepsi.

Tabel 3. Proporsi kriteria jawaban mahasiswa untuk soal nomor 1

\begin{tabular}{cccc}
\hline Kriteria Jawaban Mahasiswa & Kriteria CRI & $\begin{array}{c}\text { Jumlah } \\
\text { Mahasiswa }\end{array}$ & Prosentase \\
\hline Jawaban benar, CRI Tinggi & Menguasai konsep dengan baik & 25 & $28 \%$ \\
Jawaban benar, CRI Rendah & Tidak tahu konsep (lucky guess ) & 13 & $15 \%$ \\
Jawaban salah, CRI Rendah & Tidak tahu konsep (lack of knowledge) & 16 & $18 \%$ \\
Jawaban salah, CRI Tinggi & Terjadi miskonsepsi & 35 & $39 \%$ \\
\hline & Total & 89 & $100 \%$ \\
\hline
\end{tabular}

Dari Tabel 3 dapat diketahui bahwa proporsi mahasiswa yang mengalami miskonsepsi untuk soal nomor 1 paling tinggi dibandingkan dengan kategori lain. Secara umum, terdapat $75 \%$ mahasiswa yang melakukan kesalahan dalam menyelesaikan soal nomor 1. Dari kesalahan tersebut, proporsi yang paling tinggi yaitu jawaban salah dengan CRI tinggi atau mengalami miskonsepsi sebesar 39\%. Terdapat 25 orang yang memahami konsep dengan baik. Hal ini menunjukkan bahwa sebagian besar mahasiswa mengalami miskonsepsi dan tidak tahu konsep baik karena bermodalkan tebakan (Waluyo, E. M., Muchyidin \& Kusmanto, 2019) maupun karena masih minimnya pengetahuan yang dimiliki.

Dari hasil wawancara diketahui bahwa mahasiswa ini kurang memahami maksud pada soal dan belum mampu membedakan mana yang termasuk himpunan dan bukan himpunan. Baginya, pilihan B dan C sudah memiliki anggota sedangkan pilihan A belum ada anggota yang pasti sehingga dia berpikir bahwa pilihan A dapat membentuk suatu kumpulan menjadi dua jenis yaitu himpunan mahasiswa ganteng dan himpunan mahasiswa cantik.

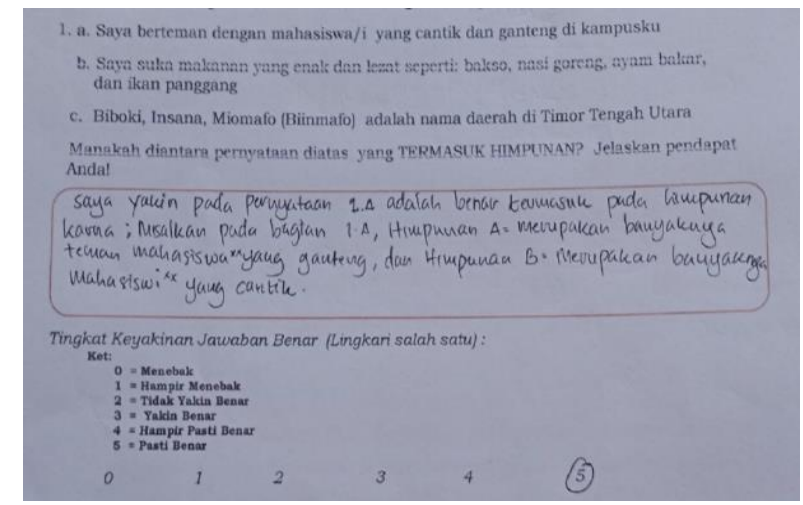

Gambar 1. Jawaban salah, CRI tinggi

Selanjutnya pada Gambar 1 merupakan salah satu jawaban mahasiswa yang mengalami miskonsepsi untuk soal nomor 1 dimana mahasiswa tersebut memberikan jawaban yang salah namun dengan keyakinan yang sangat tinggi. Dari hasil pekerjaan mahasiswa menunjukkan bahwa mahasiswa tidak mampu membedakan mana yang termasuk himpunan dan mana yang bukan himpunan bahkan pernyataan sub bagian dipecahkan menjadi dua pernyataan berbeda. Akibat miskonsepsi ini membuat mahasiswa tidak menjawab apa yang menjadi maksud pertanyaan pada soal. Hal ini sejalan dengan hasil penelitian Kefi (2021) yang mengatakan bahwa siswa memberikan jawaban yang salah dengan indeks CRI tinggi (Kefi et al., 2021). 
Tabel 4. Proporsi kriteria jawaban mahasiswa untuk soal nomor 2

\begin{tabular}{cccc}
\hline Kriteria Jawaban Mahasiswa & Kriteria CRI & $\begin{array}{c}\text { Jumlah } \\
\text { Mahasiswa }\end{array}$ & Prosentase \\
\hline Jawaban benar, CRI Tinggi & Menguasai konsep dengan baik & 10 & $11 \%$ \\
Jawaban benar, CRI Rendah & Tidak tahu konsep (lucky guess) & 28 & $31 \%$ \\
Jawaban salah, CRI Rendah & Tidak tahu konsep (lack of knowledge) & 40 & $45 \%$ \\
Jawaban salah, CRI Tinggi & Terjadi miskonsepsi & 11 & $12 \%$ \\
\hline & Total & 89 & $100 \%$ \\
\hline
\end{tabular}

Dari Tabel 4 terlihat bahwa jumlah mahasiswa yang mengalami miskonsepsi adalah 11 (12\%) dan memiliki keyakinan CRI tinggi tetapi jawaban salah pada soal nomor dua ini. Tabel 4 juga menunjukkan bahwa, cukup banyak mahasiswa, yaitu 45\% tidak tahu konsep bilangan prima yang kurang dari 17, mahasiswa menjawab bilangan prima yang kurang dari 9 seperti pada
Gambar 2 dan jawabannya benar pada soal nomor dua, walupun tingkat keyakinan CRI rendah. Ada $31 \%$ mahasiswa yang tidak tahu konsep 6 bilangan prima pertama dan tingkat CRI rendah. Hanya ada $11 \%$ mahasiswa yang paham konsep bilangan prima dengan baik dan memiliki CRI tinggi serta jawaban mereka atas soal nomor 2 benar.

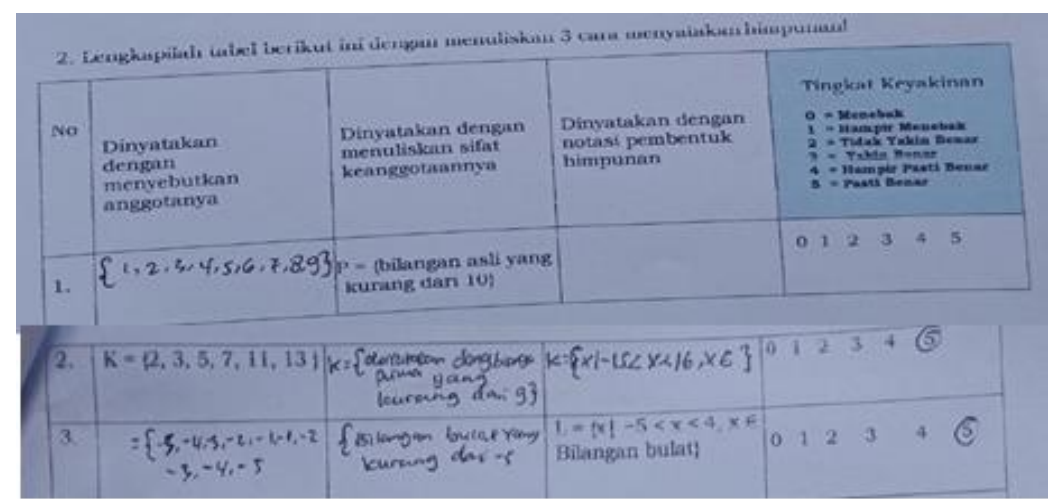

Gambar 2. Jawaban Salah, CRI tinggi 3.25 (Miskonsepsi)

Dari gambar 2, untuk soal nomor 1 mahasiswa sudah dapat menuliskankan anggota bilangan asli yang kurang dari 10 namun tidak dapat menyatakan dalam bentuk notasi himpunan dan tidak memilih indeks CRI. Untuk soal nomor 2 dan 3, dapat dilihat bahwa mahasiswa melakukan kesalahan dimana tidak paham tentang kosnep bilangan prima, belum menguasai cara menyatakan himpunandengan membuat notasi himpunan (nomor 2) dan konsep bilangan bulat (nomor 3).
Untuk indeks CRI, kedua soal tersebut mahasiswa menjawab dengan sangat yakin bahwa jawabannya benar. Hal ini dibuktikan dengan memilih tingkat keyakinan paling tinggi yaitu 5 . Oleh karena itu, jelas bahwa mahasiswa menglami miskonsepsi karena jawaban salah namun tingkat CRI tinggi. Dari hasil wawancara diketahui bahwa mahasiswa tersebut masih belum paham tentang bilangan prima, notasi himpunan dan urutan bilangan bulat.

Tabel 5. Proporsi kriteria jawaban mahasiswa untuk soal nomor 3

\begin{tabular}{cccc}
\hline Kriteria Jawaban Mahasiswa & Kriteria CRI & $\begin{array}{c}\text { Jumlah } \\
\text { Mahasiswa }\end{array}$ & Prosentase \\
\hline Jawaban benar, CRI Tinggi & Menguasai konsep dengan baik & 22 & $24 \%$ \\
Jawaban benar, CRI Rendah & Tidak tahu konsep (lucky guess) & 18 & $20 \%$ \\
Jawaban salah, CRI Rendah & Tidak tahu konsep (lack of knowledge) & 22 & $25 \%$ \\
Jawaban salah, CRI Tinggi & Terjadi miskonsepsi & 27 & $30 \%$ \\
\hline & Total & 89 & $100 \%$ \\
\hline
\end{tabular}

Dari Tabel 5 terlihat bahwa jumlah mahasiswa yang mengalami miskonsepsi adalah 27 (30\%) dan memiliki keyakinan CRI tinggi tetapi jawaban salah pada soal nomor tiga. Tabel 5 juga menunjukkan bahwa, 25\% tidak tahu konsep notasi pembentuk himpunan, mahasiswa menjawab bilangan bulat yang kurang dari -5 seperti pada
Gambar 3 dan jawabannya salah pada soal nomor tiga dengan tingkat keyakinan CRI rendah. Ada $20 \%$ mahasiswa yang tidak tahu konsep notasi himpunan dan tingkat CRI rendah, ada 24\% mahasiswa yang paham konsep notasi himpunan dengan baik dan memiliki CRI tinggi serta jawaban mereka atas soal nomor 3 benar. 


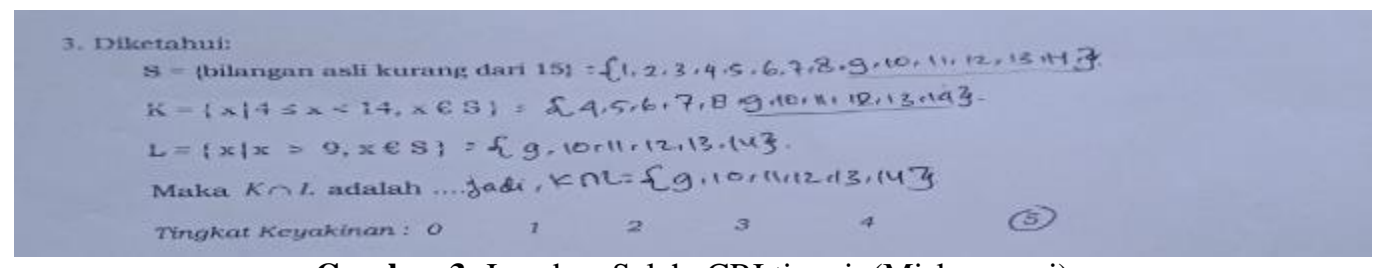

Gambar 3. Jawaban Salah, CRI tinggi (Miskonsepsi)

Gambar 3 menunjukkan bahwa terjadi miskonsepsi dimana mahasiswa salah dalam menentukan anggota $\mathrm{K}$ dan $\mathrm{L}$ namun memilih tingkat CRI tinggi. Untuk anggota himpunan $\mathrm{K}$ seharusnya tidak termasuk 14 dan anggota himpunan seharusnya dimulai dari 10. Karena kesalahan ini maka berakibat pada keslahan dalam menentukan irisan antara $\mathrm{K}$ dan $\mathrm{L}$. Dari hasil wawancara diketahui bahwa mahasiswa tersebut masih belum memahami makna pertidaksamaan seperti kurang dari $(<)$ dan lebih dari $(>)$.

Tabel 6. Proporsi kriteria jawaban mahasiswa untuk soal nomor 4

\begin{tabular}{cccc}
\hline Kriteria Jawaban Mahasiswa & Kriteria CRI & $\begin{array}{c}\text { Jumlah } \\
\text { Mahasiswa }\end{array}$ & Prosentase \\
\hline Jawaban benar, CRI Tinggi & Menguasai konsep dengan baik & 21 & $24 \%$ \\
Jawaban benar, CRI Rendah & Tidak tahu konsep (lucky guess ) & 8 & $9 \%$ \\
Jawaban salah, CRI Rendah & Tidak tahu konsep (lack of knowledge) & 43 & $48 \%$ \\
Jawaban salah, CRI Tinggi & Terjadi miskonsepsi & 17 & $19 \%$ \\
\hline & Total & 89 & $100 \%$ \\
\hline
\end{tabular}

Untuk soal nomor 4 pada Tabel 6 menyelesaikan masalah dalam kehidupan seharihari terkait himpunan terdapat $24 \%$ mengetahui konsep dengan benar, 57\% tidak tahu konsep dan 19\% mengalami miskonsepsi. Ini berarti sebagian mahasiswa hanya menjawab soal dengan menebaknya (Helmi et al., 2019; Qurrota \& Nuswowati, 2018). Miskonsepsi yang dialami mahasiswa kemungkinan berasal dari mereka sendiri, dosen ataupun buku sumber belajar (Mujib, 2017).

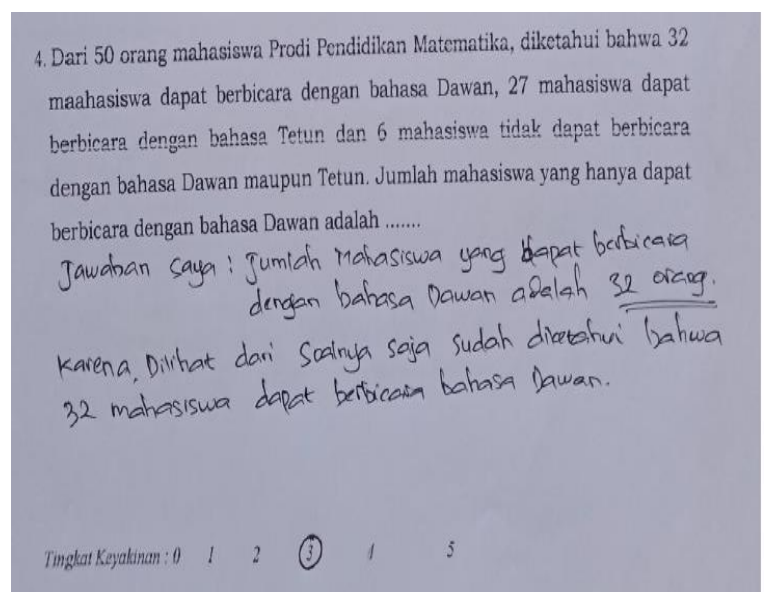

Gambar 4. Jawaban Salah, CRI Tinggi (Terjadi miskonsepsi)

Dari Gambar 4 tampak bahwa terjadi miskonsepsi dimana mahasiswa tidak dapat menyelesaikan soal dengan benar namun memilih tingkat keyakinan yang tinggi. Dari hasil wawancara diketahui bahwa mahasiswa tersebut masih belum memahami maksud pada soal hanya menuliskan ulang saja informasi pada soal tanpa melakukan langkah-langkah penyelesaian dengan baik.

Untuk soal nomor 1 pada Tabel 3 tentang definisi himpunan, terdapat $28 \%$ yang mengetahui konsep dengan benar, 33\% tidak tahu konsep dan $39 \%$ mengalami miskonsepsi. Hasil ini sejalan dengan Fitria (2014b) bahwa peserta didik yang menemui miskonsepsi lebih banyak dari pada mahasiswa yang tahu konsep dan tidak tahu konsep (Alonemarera, 2020; Saragih, 2018). Untuk soal nomor 2 pada Tabel 4 tentang tiga cara menyajikan himpunan, $11 \%$ mengetahui konsep dengan benar, 76\% tidak tahu konsep karena menebak dan kurangnya pengetahuan, sisanya $12 \%$ mengalami miskonsepsi, $87 \%$ mahasiswa kesulitan dalam menyajikan himpunan dalam bentuk notasi pembentuk himpunan. Untuk soal nomor 3 pada Tabel 5 tentang operasi himpunan (irisan): $24 \%$ mengetahui konsep dengan benar, $45 \%$ tidak tahu konsep dan 30\% mengalami konsepsi. Artinya mahasiswa yang tidak paham konsep lebih banyak dan tidak menjawab dengan salah, mahasiswa melakukan kesalahan operasi, sehingga mengalami miskonsepsi (Aygor \& Ozdag, 2012).

\section{Kesimpulan}

Mahasiswa yang mengikuti perkuliahan Pengantar Dasar Matematika terbukti mengalami miskonsepsi pada materi himpunan. Adapun proporsi mahasiswa yang mengalami miskonsepsi, tidak tahu konsep karena menebak, tidak tahu konsep karena kurangnya pengetahuan dan tahu 
konsep dengan benar sangat bervariasi antara nomor soal.

Dari empat soal yang diberikan, mahasiswa paling banyak mengalami miskonsepsi pada soal nomor $1(39 \%)$ kemudian diikuti soal nomor 3 sebesar 30\%. Sementara itu, soal yang paling banyak tidak ditemukan mahasiswa mengalami miskonsepsi yaitu soal nomor 2. Meskipun demikian, berdasarkan kriteria CRI pada soal tersebut ditemukan hampir 50\% mahasiswa termasuk dalam kategori tidak tahu konsep karena kurangnya pengetahuan dan 30\% karena menebak saja.

\section{Ucapan Terima Kasih}

Peneliti mengucapkan terima kasih kepada Universitas Timor selaku penyandang dana melalui Hibah Lembaga Penelitian dan Pengabdian pada Masyarakat (LPPM) Tahun Angggaran 2020 dengan nomor kontrak 43/UN60/LPPM/PP/2020. Ucapan terima kasih yang sama juga disampaikan kepada semua mahasiswa yang terlibat dalam penelitian ini.

\section{Daftar Pustaka}

Alonemarera, A. S. (2020). Identifikasi Miskonsepsi Mahasiswa Pendidikan Biologi Pada Materi Genetika Menggunakan Certainty of Response Indeks (Cri). Jurnal Biotek, 8(2), 109. https://doi.org/10.24252/jb.v8i2.16320

Aygor, N., \& Ozdag, H. (2012). Misconceptions in Linear Algebra: the Case of Undergraduate Students. Procedia - Social and Behavioral Sciences, 46(2002), 2989-2994. https://doi.org/10.1016/j.sbspro.2012.05.602

Fadillah, S. (2017). Analisis Miskonsepsi Siswa Smp Dalam Materi Perbandingan Dengan Menggunakan Certainty of Response Index (Cri). Jurnal Pendidikan Informatika Dan Sains, $5(2)$, 247-259. http://www.journal.ikippgriptk.ac.id/index.php/s aintek/article/view/349

Fitria, A. (2014a). Miskonsepsi Mahasiswa Dalam Menentukan Grup Pada Struktur Aljabar Menggunakan Certainty Of Response Index (Cri) Di Jurusan Pendidikan Matematika IAIN Antasari. Jurnal Pendidikan Matematika, 1(2), 45-60. https://doi.org/10.18592/jpm.v1i2.50

Fitria, A. (2014b). Miskonsepsi Mahasiswa Dalam Menentukan Grup Pada Struktur Aljabar Menggunakan Certainty Of Response Index (Cri) Di Jurusan Pendidikan Matematika IAIN Antasari. Jurnal Pendidikan Matematika, 1(2), 45. https://doi.org/10.18592/jpm.v1i2.50
Hasan, S., Bagayoko, D., \& Kelley, E. L. (1999). Misconceptions and the certainty of response index (CRI). Physics Education, 34(5), 294-299. https://doi.org/10.1088/0031-9120/34/5/304

Helmi, H., Rustaman, N. Y., Tapilow, F. S., \& Hidayat, T. (2019). Preconception analysis of evolution on pre-service biology teachers using certainty of response index. Journal of Physics: Conference Series, 1157(2). https://doi.org/10.1088/17426596/1157/2/022033

Kefi, M. E., Disnawati, H., \& Suddin, S. (2021). Analisis Kesulitan Siswa Dalam Menyelesaikan Soal Relasi Menggunakan Certainty of Response Index (Cri). Jurnal Pendidikan Matematika (Jupitek), 4(1), 21-26. https://doi.org/10.30598/jupitekvol4iss1pp21-26

Mujib, A. (2017). I Dentifikasi M Iskonsepsi M Ahasiswa M Enggunakan Cri Pada. Mushorafa, 6(2), 181-192.

Putra, I. E., Adlim, A., \& Halim, A. (2016). Analisis Miskonsepsi Dan Upaya Remediasi Pembelajaran Listrik Dinamis Dengan Menggunakan Media Pembelajaran Lectora Inspire Dan PhET Simulation Di Sman Unggul Tunas Bangsa. Jurnal Pendidikan Sains Indonesia (Indonesian Journal of Science Education), 4(2), 13-19

Putri, R.E., Hasan, S. (2021). Analisis Miskonsepsi Menggunakan Metode Four-Tier Certainty Of Response Index: Studi Eksplorasi Di Smp Negeri 60 Surabaya. Pensa E-Jurnal: PENDIDIKAN SAINS, 9(2), 220-226.

Qurrota, A., \& Nuswowati, M. (2018). Analisis Miskonsepsi Siswa Menggunakan Tes Diagnostic Multiple Choice Berbantuan Cri (Certainty of Response Index). Jurnal Inovasi Pendidikan Kimia, 12(1), 2108-2117.

Rahmawati, N. K., Kusuma, A. P. (2019). Hubungan Pemahaman Konsep Aritmatika Sosial Dengan Hasil Belajar Ips Materi Pph. Buana Matematika: Jurnal Ilmiah Matematika Dan Pendidikan Matematika, 9(1:), 1-6. https://doi.org/10.36456/buana_matematika.9.1: .1976.1-6

Ramadhan, Y., Nisa, K., R., \& Sunarwin, S. (2020). Analysis of Students Misconception Using Certainly of Response Index (CRI) in the Periodic System of Elements Concept. EduChemia (Jurnal Kimia Dan Pendidikan), $5(2)$, 210 . https://doi.org/10.30870/educhemia.v5i2.8285

Sadhu, S., Tima, M. T., Cahyani, V. P., Laka, A. F., Annisa, D., \& Fahriyah, A. R. (2017). Analysis of acid-base misconceptions using modified certainty of response index (CRI) and diagnostic interview for different student levels cognitive. International Journal of Science and Applied Science: Conference Series, 1(2), 91. https://doi.org/10.20961/ijsascs.v1i2.5126

Saragih, A. (2018). Kelas Xi Mipa Sma Analysis Of Student' $\mathrm{S}$ Misconceptions On The Concepts Of The Human Nervous System Using Concept Map In Class XI MIPA SMA Adelina Saragih 
Universitas Negeri Medan, Medan Email: saragihadelina3@gmail.com PENDAHULUAN Penelitian ini berti. Prosiding Seminar Nasional Biologi Dan Pembelajarannya Universitas Negeri Medan.

Suwarna, I. P. (2017). Analisis Miskonsepsi Siswa Sma Kelas X Pada Mata Pelajaran Fisika Melalui Cri I (Certainty Of Response Index) Termodifikasi. Prisiding.

Treagust, D. F. (2012). Diagnostic assessment in science as a means to improving teaching, learning and retention. UniServe Science Assessment Symposium Proceedings, 1(1), 1-9. http://www.tamu.edu/mars/assess/HTMLfiles/o abooks.html\%0Ahttp://www.edu.uszeged.hu/ csapo/publ/Reading_Framework_En glish.pdf\#page=215\%0Ahttp://www.ntk.hu/c/do cument_library/get_file?uuid=4fdfc630-1445-

41e5-b8ab-

2020c6a135cc\&groupId=10801\%0Ahttp://openj ou

Udil, Afrisno, Amsikan, P., \& Oktovianus, N. (2020). Analisis Miskonsepsi Siswa Kelas Viii Smpn Loro Tuan Pada Materi Pola Bilangan Dengan Certanty of Response Index (Cri). Asimtot: Jurnal Kependidikan Matematika, 2(2), 139 152. https://doi.org/10.30822/asimtot.v2i2.770

Waluyo, E. M., Muchyidin, A., \& Kusmanto, H. (2019). Analysis of Students Misconception in Completing Mathematical Questions Using Certainty of Response Index (CRI). Tadris: Jurnal Keguruan Dan Ilmu Tarbiyah, 4(1), 2739. https://doi.org/10.24042/tadris.v4i1.2988 